\title{
Herbal Tea
}

National Cancer Institute

\section{Source}

National Cancer Institute. Herbal Tea. NCI Thesaurus. Code C87562.

An aqueous extract derived from parts of various plants, but excluding that made from the leaves of the real tea bush Camellia sinensis. The parts used can be fresh or dried leaves, roots, seeds and flowers. 